
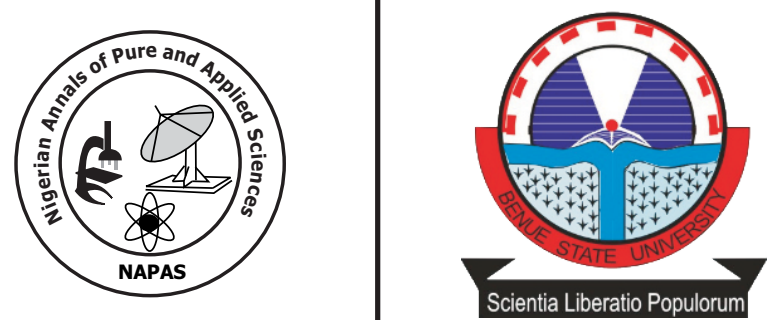

\title{
Determination of Efficiency Parameters in tin Halide Perovskite Solar Cells
}

\author{
Ikyo, B.A. ${ }^{1}$ Ochai, A.F. ${ }^{2}$ and Itodo, A. $^{3}$ \\ Department of Physics, \\ Benue State University, Makurdi.
}

Corresponding authors: ikyo12@yahoo.com, abutufrancis30@gmail.com and ianejo@yahoo.com

\section{Abstract}

Perovskite solar cells have gained significant attention in photovoltaic research. Just within a few years, the efficiencies of perovskite-based solar cells have been improved significantly to over $20 \%$ which makes them comparably efficient to silicon-based solar cells. The reason for such high recorded efficiencies are due to perovskites ease of processing, a high carrier diffusion length, low exciton binding energy and high absorption coefficient. Theoretical calculations were carried out based on the detailed balanced model on some Tin Halide Perovskite absorbers. For $\mathrm{CH}_{3} \mathrm{NH}_{3} \mathrm{SnI}_{3}$, results obtained for $\mathrm{V}_{\mathrm{oc}} \mathrm{J}_{\mathrm{oc}}$, FF and $\mathrm{n}$ are $1.14 \mathrm{~V}, 34.4 \mathrm{~mA} / \mathrm{cm}_{2}, 0.725$ and $5.56 \%$ respectively. For $\mathrm{CH}_{3} \mathrm{NH}_{3} \mathrm{SnIBr}_{2}$ values obtained for $\mathrm{V}_{\text {oc }} \mathrm{J}_{\mathrm{oc}}, \mathrm{FF}$ are $1.37 \mathrm{~V}, 24.03 \mathrm{~mA} / \mathrm{cm}^{2}, 0.784$ and $5.22 \%$ respectively. For $\mathrm{CH}_{3} \mathrm{NH}_{3} \mathrm{SnI}_{2} \mathrm{Br}$ values obtained for $\mathrm{V}_{\text {oc }} \mathrm{J}_{\mathrm{oc}}, \mathrm{FF}$ are $1.38 \mathrm{~V}, 20.04 \mathrm{~mA} / \mathrm{cm}^{2}, 0.810$ and $4.69 \%$ Also for $\mathrm{CH}_{3} \mathrm{NH}_{3} \mathrm{SnBr}_{3}$, results obtained forV $\mathrm{V}_{\text {oc }} \mathrm{J}_{\mathrm{oc}}$, FF are $1.44 \mathrm{~V}, 14.52 \mathrm{~mA} / \mathrm{cm}^{2}, 0.881$ and $3.21 \%$ respectively. 


\section{Introduction}

Perovskite solar cells are presently considered leading hybrid solar cells materials due to their ease of fabrication, high solar absorption coefficient and low non-radiative carrier recombination rates (Amu, 2014), and the relative increase in the power conversion efficiency of perovskite solar cells $\left(\mathrm{CH}_{3} \mathrm{NH}_{3} \mathrm{PbI}_{3}\right)$ which has risen from as low as 3.6\% to as high as $20 \%$ in just five years with yet a projected value of over $20 \%$ in the next few years by experimentalist (Snaith et al., 2014).

However, the presence of lead in the high efficiency perovskite halides such as $\left(\mathrm{CH}_{3} \mathrm{NH}_{3} \mathrm{PbI}_{3}\right)$ is an impediment in the use of perovskite solar cells for most technological applications and as such a possible substitute for lead in the perovskite structure is sought. Amongst other element to be considered as substitute for lead in the perovskite structure, tin stands out as a suitable substitute, because tin has a similar $\mathrm{s}^{2}$ valence electronic configuration to lead, and similar ionic radius (Pb:119pm, Sn: 110pm), which makes it possible to form a perovskite with a basic formular $\left(\mathrm{ABX}_{3}\right)$ in analogy to lead compounds (Chen et al., 2015).

Different authors have worked on perovskite solar cells as recorded in the literature. The authors in (Xiangang et al., 2017), through integrating the detailed balance theory with the drift diffusion model, considering only radiative recombination as the only recombination mechanism within the perovskite solar cell $\left(\mathrm{CH}_{3} \mathrm{NH}_{3} \mathrm{PbI}_{3}\right)$ and the influence of both selective and non-selective contact obtained an efficiency of $23.83 \%$ for selective contacts and an efficiency of $29.86 \%$ for non-selective contacts.

While (Granas et al., 2016) established the limit of efficiency of some metal-halide perovskites from first principles modelling and arrived at an efficiency range of $25-27 \%$ with a bandgap range of 1.1-1.6eV for most of the hybrid organic-inorganic compounds. In establishing the theoretical efficiency, they assume ideal interfaces and defect free crystals. Their result was able to show a direct relation between higher efficiencies and the device engineering of both the perovskite absorber layer and carrier transporting materials of the solar cell.

Similarly, the authors (Noel et al., 2014), considering $\left(\mathrm{CH}_{3} \mathrm{NH}_{3} \mathrm{SnI}_{3}\right)$ and $\left(\mathrm{CH}_{3} \mathrm{NH}_{3} \mathrm{SnBr}_{3}\right)$ with bandgap values of $1.3 \mathrm{eV}$ and $1.56 \mathrm{eV}$ respectively, employing the density functional theory (DFT) estimated their respective efficiency values at $6.4 \%$ and $4.32 \%$ respectively.

With angular restriction, the authors (Sha et al., 2014) exploring the detailed balance model, calculated the efficiency limit of $\left(\mathrm{CH}_{3} \mathrm{NH}_{3} \mathrm{PbI}_{3}\right)$ perovskite solar cell on both flat and textured surface architecture with consideration of photon recycling effect light-trapping designs still play an important role in improving the efficiency of thinfilm perovskite cells, even if perovskite material has a strong optical absorption their shows power conversion efficiency (PCE) as a function of cell thickness. The PCE limit of the perovskite cell is about 31\%, which approaches to the ShockleyQueisser limit (33\%) achievable by gallium arsenide (GaAs) solar cells (Wehrenfennig et al., 2014).

Considering radiative losses as the only recombination mechanism within the cell, and applying the detailed balance model (Ugwuoke, 2014), in his work, arrived at a limiting efficiency of $27.5 \%$ for $\left(\mathrm{CH}_{3} \mathrm{NH}_{3} \mathrm{PbI}_{3-\mathrm{x}} \mathrm{CI}, 29.2 \%\right.$ for $\left(\mathrm{CH}_{3} \mathrm{NH}_{3} \mathrm{PbI}_{3}\right)$. His result shows that for thicker absorbers the short-circuit current density will be higher and conversely for thinner absorber. The reason for this is that charge collection at shortcircuit is always assisted by the electric field in the absorber. Also, that thinner absorbers give the highest open-circuit voltage and for Fill Factor, he observed a quick drop in Fill Factor as the absorber thickness increases. The result shows that thicker absorbers give high efficiency.

Using a simulator device known as the solar cell capacitance simulator (SCAPS) (Amu, 2014) developed a configuration with reduced acceptor doping concentration of the absorber layer, and this configuration was used to solve the Poisson and hole and electron continuity equations in order to obtain relevant properties of tin-based perovskites solar cells, arrived at a theoretical efficiency of approximately $6.4 \%$. From his result, he observed that there is a decrease in device performance as doping concentration in the perovskite material increases. He was able to establish that doping concentration increases recombination and reduces the lifetime of charge carriers.

While much work has been done on lead halide perovskite solar cells, there are relatively few reports on tin halide perovskite solar cells. Additionally, there is need to develop models to complement experimental work which are relatively difficult to understand. To this end, this work aims to explore a theoretical model that can be used to efficiently reduce the identified energy losses and improve the overall cell conversion efficiency which will serve as benchmark for possible design and fabrication of technologically efficient Tin-Halide based perovskite solar cells. 


\section{Theoretical background}

The main parameters that are used to characterize the performance of solar cells are the peak power $\left(\mathrm{P}_{\max }\right)$, the short-circuit current density
$\left(\mathrm{J}_{\mathrm{sc}}\right)$, the open-circuit voltage $\left(\mathrm{V}_{\mathrm{oc}}\right)$, the Fill Factor $(F F)$, and photoelectric efficiency $(\eta)$ These parameters are determined from the $\mathrm{J}-\mathrm{V}$ characteristic curve as illustrated in Figure 1:

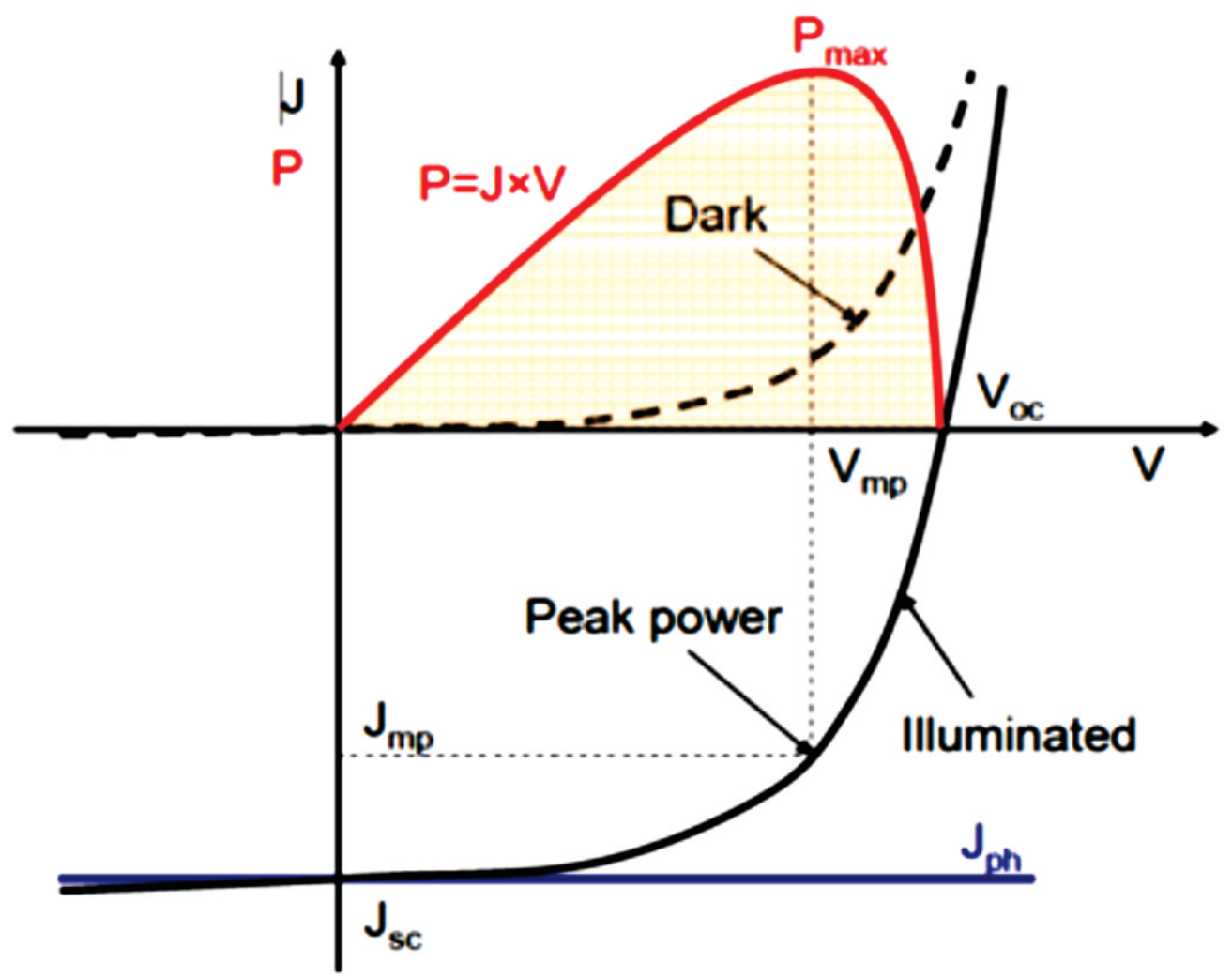

Figure 1: J-V characteristic parameters of a p-n junction in the dark and under illumination (Nelson, 2003)

\section{Short-Circuit Current Density $\left(J_{s c}\right)$}

The short-circuit current density measured in $\mathrm{mA} / \mathrm{cm}^{2}$ is the maximum photo-generated current delivered by a solar cell when the solar cell is not matched to an external load or when matched to a load with a zero resistance $(\mathrm{V}=0)$.

The short-circuit current density of a solar cell depends on the photon flux density incident on the solar cell, the area of solar cell under illumination, the number of photo-generated charge carriers and their separation and collection rates in the external circuit (Heo et al., 2013).

$\mathrm{J}_{\mathrm{sc}}=\mathrm{q} \phi(\mathrm{E})$

\section{Open-Circuit Voltage $\left(V_{\text {oc }}\right)$}

The Open-circuit voltage $\left(\mathrm{V}_{\mathrm{oc}}\right)$ measured in volts $(\mathrm{V})$ is the voltage at which no current flows through the external circuit when the terminals of the solar cell are not connected to each other or when it is matched to a load with infinite resistance $(\mathrm{J}=0)$. It is the maximum voltage that a solar cell can deliver. The open-circuit voltage depends on the photo-generated current density $\left(\mathrm{J}_{\mathrm{sc}}\right)$ and the saturation current density $\left(\mathrm{J}_{0}\right)$. For the simple $\mathrm{p}-\mathrm{n}$ junction, we have (Amu, 2014):

$\mathrm{V}_{\mathrm{oc}}=\mathrm{V}_{\mathrm{c}} \ln \left(\frac{\mathrm{J}_{\mathrm{sc}}}{\mathrm{J}_{0}}+1\right)$
Where $\quad V_{c}=\frac{K T}{q} \mathrm{~K}$ is the Boltzmann constant and

Tis temperature and $\mathrm{q}$ is the electronic charge.

\section{Fill Factor}

The fill factor is defined as the ratio of the maximum theoretical power from the solar cell $\left(P_{\max }=J_{m p} \times V_{m p}\right)$ generated by a solar cell and the product of the open circuit voltage $\left(\mathrm{V}_{\mathrm{oc}}\right)$ and the short circuit current $\left(\mathrm{J}_{\mathrm{sc}}\right)(\mathrm{Ugwuoke}, 2014)$ :

$$
\mathrm{FF}=\frac{\mathrm{V}_{\mathrm{mp}} J_{\mathrm{mp}}}{\mathrm{V}_{\mathrm{oc}} J_{\mathrm{sc}}}=\frac{\mathrm{P}_{\max }}{\mathrm{V}_{\mathrm{oc}} J_{\mathrm{sc}}}
$$

$\mathrm{V}_{\mathrm{mp}}$ and $\mathrm{J}_{\mathrm{mp}}$ are the maximum point voltage and current density generated by a solar cell. The fill factor is essentially a measure of quality of a solar cell. The values of the fill factor range from 0.80 0.95 but never approaches 1.0 except for a lossless solar cell (Heo et al., 2013). The fill factor quantifies the efficiency of the transport and extraction of the charges in a solar cell, hence is not influenced only by the active material, but also by the device design and architecture.

\section{Photoelectric Efficiency of Solar Cells}

The photoelectric efficiency $(\eta)$, which describes the ability of the solar cell to convert 
light energy to electrical energy, is the ratio of maximum power generated to the incident solar irradiance. It is the percentage of power that can be converted from photo-generated current to useable electricity when a solar cell is connected to an external circuit (Heo et al., 2013):

$\eta=\frac{\mathrm{J}_{\mathrm{sc}} \mathrm{V}_{\mathrm{oc}} \mathrm{FF}}{\mathrm{P}_{\text {in }}} \times 100 \%$

\section{Estimation method}

\section{The detailed balance model}

The principle of detailed balance states that "A sample is said to be in thermodynamic equilibrium when the temperature of the sample is the same as the temperature of its environment, when there is no change of temperature in time, and when there is no external forces acting on the sample for instance an applied voltage or excess illumination from a light source. If a sample is in thermal equilibrium, then all microscopic processes in the sample are exactly compensated by their respective inverse process" (Darrow, 1924).

The calculations in this model involves calculating the absorption flux and emitted flux from a solar cell. The difference between these two multiplied by the electronic charge (q) is the current from the solar cell (Shockley and Quiesser, 1961).

The detailed balanced model (a thermodynamical balanced model) is based on the statistical balance between generated exciton and the possible recombination within the solar cell. In order to determine the efficiency, we shall consider the following assumptions;

i. The solar cell has an infinite thickness and hence an infinite volume.

ii. Infinite charge mobility, allowing collection of carriers no matter where they are generated.

iii. Radiative band-to-band (bimolecular) recombination mechanism is the only existing loss mechanism. Non radiative recombination, such as Auger recombination and Trap assisted recombination is ignorable. The term for radiative recombination from the semiconductor follows from the Van Roosbroeck Shockley (VRS) relation (VanRoosbroeck et al., 1954).

iv. Quantum efficiency reaches $100 \%$. When a photon is absorbed, it produces one electron-hole pair, and when one electronhole pair recombines, it produces one photon. A single electron-hole pair is created per absorbed photon and it is extracted at a voltage
$\mathrm{V}_{\mathrm{g}}=\mathrm{E}_{\mathrm{g} / \mathrm{q}}$

The absorption and emission of photons follows a step function:

$a(E) / e(E)=\left\{\frac{1 \text { for } E \geq E_{g}}{0 \text { for } E<E_{g}}\right\}$

For a steady state condition, the total rate of photon emission must be the same as the rate at which photons are absorbed corrected by the fraction that is drawn off as current. Hence we can write (Green et al., 2014):

$\mathrm{J}(\mathrm{V})=\mathrm{q}\left(\mathrm{R}_{\text {gen }}-\mathrm{R}_{\text {rec }}^{\mathrm{rad}}-\mathrm{R}_{\text {rec }}^{\text {non-rad }}\right)$

Where $R_{g e n}$ is the rate of generation of electronhole pair due to absorption of incident photons from the sun which is equal to the photon flux $\mathrm{R}_{\mathrm{gen}}=\phi(\mathrm{E})$ )

$\mathrm{R}_{\mathrm{rec}}^{\mathrm{rad}}$ is the rate of radiative recombination of the photo-generated carriers.

$\mathrm{R}_{\mathrm{rec}}^{\text {non-rad }}$ is the total rate of non- radiative recombination which is equal to zero $\mathrm{R}_{\mathrm{rec}}^{\text {non-rad }}=0$ )

$\mathrm{V}$ is the applied voltage of the solar cell.

$\mathrm{J}$ is the current extracted from the cell per unit area (Van-Roosbroeck et al., 1954):

$J=q\left[\frac{2 \Omega_{s}}{h^{3} C_{o}^{2}} \int_{0}^{\infty} a(E) \frac{E^{2} d E}{\exp \left(\frac{E}{K T_{s}}\right)-1}-\frac{2 \pi n^{2}}{h^{3} C_{o}^{2}} \int_{0}^{\infty} e(E) \frac{E^{2} d E}{\exp \left(\frac{E}{K T_{c}}\right)-1}\right] 6$

This allows us to define the photo-generated current density as:

$\mathrm{J}_{\mathrm{ph}}=\mathrm{q} \phi(\mathrm{E})$

Also we can define the radiative current as (Ugwuoke, 2014):

$\mathrm{J}_{\mathrm{rad}}=\mathrm{qR}_{\mathrm{rec}}^{\mathrm{rad}}=\mathrm{J}_{0}\left(\exp \left(\frac{\mathrm{qV}}{\mathrm{KT}_{\mathrm{c}}}\right)-1\right.$

Where

$V_{c}$ is the solar cell voltage

$\mathrm{V}_{\mathrm{c}}=\frac{\mathrm{KT}_{\mathrm{c}}}{\mathrm{q}}$

$\mathrm{J}_{0}$ is the dark saturation current

$\mathrm{T}_{c}$ is the solar cell temperature

$\mathrm{q}$ is electronic charge

This follows that

$$
\begin{aligned}
& \mathrm{J}_{\mathrm{rad}}=\mathrm{J}_{0}\left(\exp \left(\frac{\mathrm{V}}{\mathrm{V}_{\mathrm{c}}}\right)-1\right) \\
& \mathrm{J}(\mathrm{V})=\mathrm{J}_{\mathrm{SC}}-\mathrm{J}_{0}\left(\exp \left(\frac{\mathrm{V}}{\mathrm{V}_{\mathrm{c}}}\right)-1\right) \\
& \mathrm{J}(\mathrm{V})=\left(\mathrm{J}_{\mathrm{sc}}-\mathrm{J}_{0}\right)+\mathrm{J}_{0}\left(1-\exp \left(\frac{\mathrm{V}}{\mathrm{V}_{\mathrm{c}}}\right)\right.
\end{aligned}
$$


Under illumination, $\mathrm{J}_{\mathrm{sc}}-\mathrm{J}_{0} \approx \mathrm{J}_{\mathrm{sc}}$

$\mathrm{J} V=\mathrm{J}_{\mathrm{sc}}+\mathrm{J}_{0}\left(1-\exp \left(\frac{\mathrm{V}}{\mathrm{V}_{\mathrm{c}}}\right)\right.$

Where $\mathrm{J}_{\mathrm{sc}}$ is the current generated from the solar cell at $\mathrm{V}=0$, defined as the photgenerated current $\left(\mathrm{J}_{\mathrm{sc}}=\mathrm{J}_{\mathrm{ph}}\right)$

Hence, the current extracted from the solar cell at maximum power $\left(J_{\mathrm{mp}}\right)$ is given as

$\mathrm{J}_{\mathrm{mp}}=\mathrm{J}_{\mathrm{sc}}+\mathrm{J}_{0}\left(1-\exp \left(\frac{\mathrm{V}_{\mathrm{mp}}}{\mathrm{V}_{\mathrm{c}}}\right)\right.$

Also, the voltage at maximum power $\left(\mathrm{V}_{\mathrm{mp}}\right)$ can be determined by combining (13) and (12) which yields (14):

$\mathrm{V}_{\mathrm{mp}}=\mathrm{V}_{\mathrm{oc}}+\mathrm{V}_{\mathrm{c}} \operatorname{In}\left(1-\exp \frac{\mathrm{V}_{\mathrm{oc}}}{\mathrm{V}_{\mathrm{c}}}\right)$

\section{Theoretical method for predicting efficiency parameters}

The theoretical methods for predicting $J_{\mathrm{sc}}, \mathrm{V}_{\mathrm{oc}}, \mathrm{FF}$, and $\eta$ have been established in equations (1), (2), (3), and (4) respectively. The results obtained for the bandgap energy range be used in this work are given in the next chapter with details of their validation also established.

\section{Results}

Estimated parameter values of the present theoretical method (PTM) and those from reference method for tin halide perovskite solar cells with $\mathrm{E}_{\mathrm{g}}(\mathrm{eV})$ at 1.30, 1.56, 1.65 and 2.15 are presented in Figures 2-5 for validation.

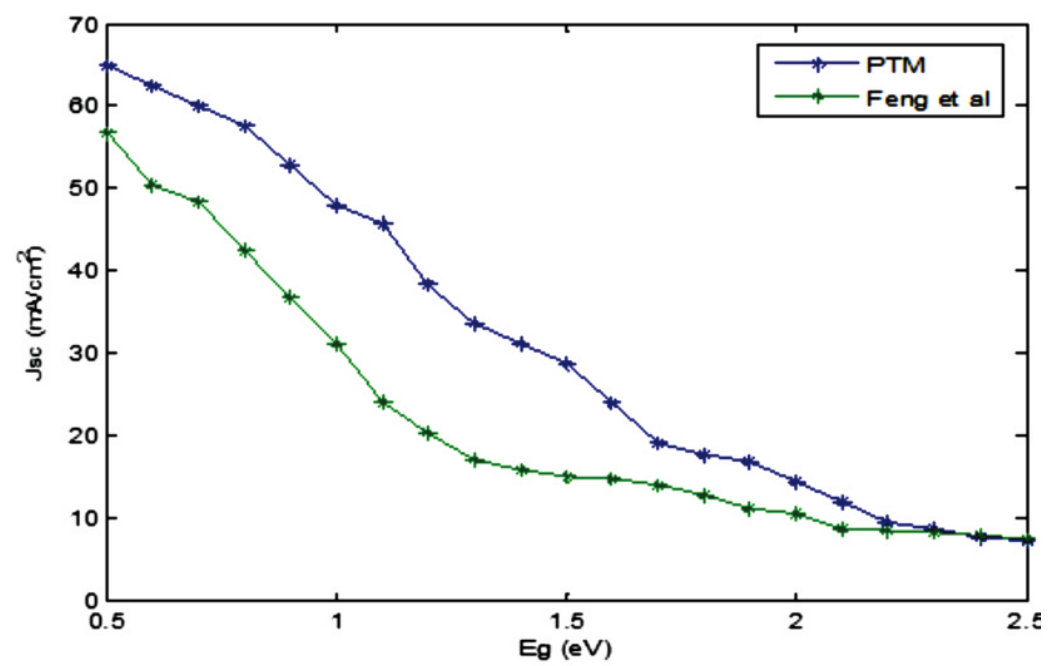

Figure 2: Present theoretical method in comparison with referenced method for $\mathrm{J}_{\mathrm{sc}}$

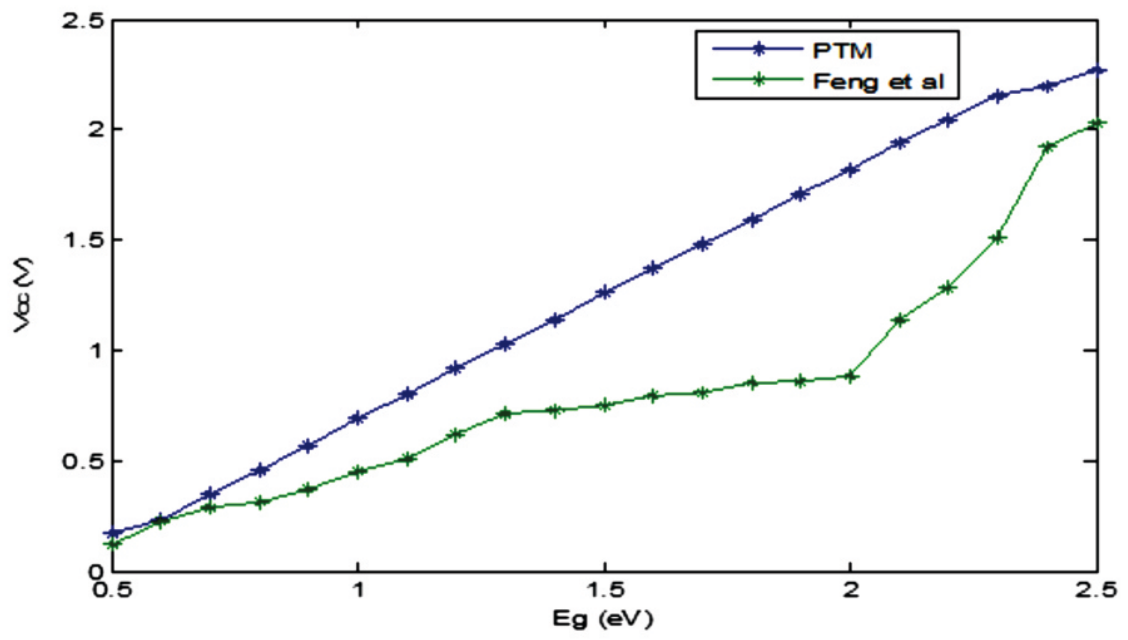

Figure 3: Present theoretical method in comparison with referenced method for $V_{o c}$ 


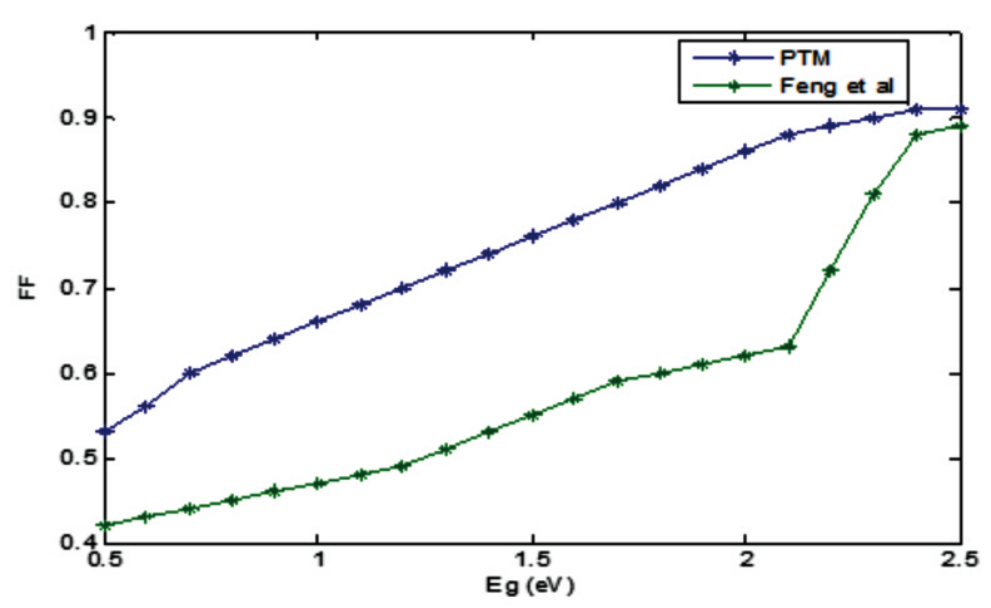

Figure 4: Present theoretical method in comparison with reference work for FF

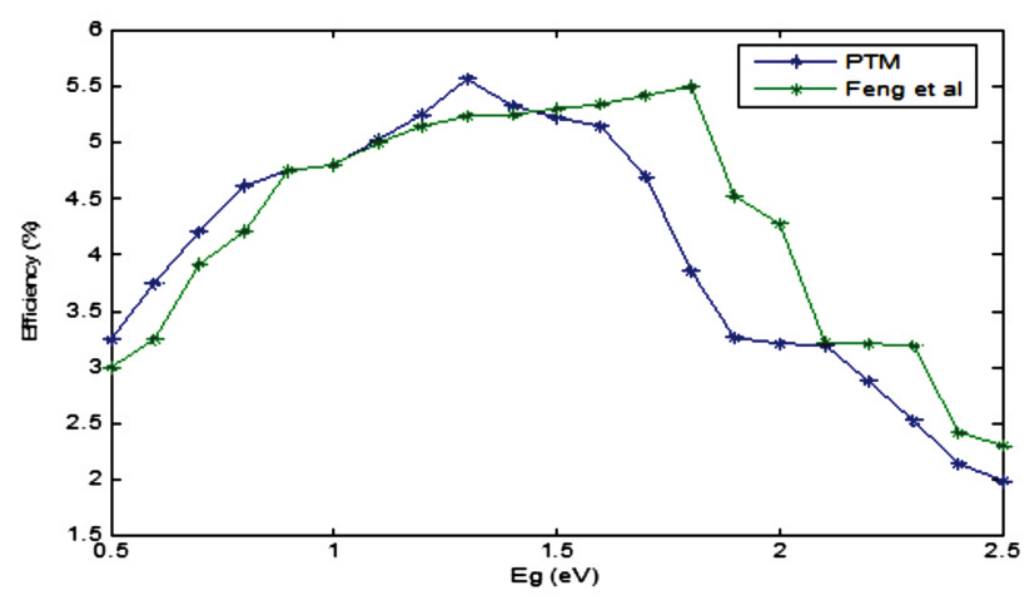

Figure 5: Present theoretical method in comparison with referenced work for $\eta$

\section{Discussion}

Figure 2 shows the representation for the short circuit current density $\left(\mathrm{J}_{\mathrm{sc}}\right)$ versus band gap $(\mathrm{Eg})$. From the Figure, we see a decrease in $\mathrm{J}_{\mathrm{sc}}$ with increasing Eg. This happens because at shortcircuit condition, the solar cell is expected to encounter no recombination, and that charge collection is always assisted by the inbuilt absorber electric field. Therefore, efficient light absorption requires smaller band gap $\left(\mathrm{Eg}_{\mathrm{g}}\right)$ materials. Hence we observed high $\mathrm{J}_{\mathrm{sc}}$ in $\mathrm{CH}_{3} \mathrm{NH}_{3} \mathrm{SnI}_{3}$ with $\mathrm{Eg}=1.30$ as compared to $\mathrm{CH}_{3} \mathrm{NH}_{3} \mathrm{SnIBr}_{3}$ with $\mathrm{Eg}=1.75, \mathrm{CH}_{3} \mathrm{NH}_{3} \mathrm{SnI}_{2} \mathrm{Br}$ with $\mathrm{E}_{\mathrm{g}}=1.56$ and $\mathrm{CH}_{3} \mathrm{NH}_{3} \mathrm{SnBr}_{3}$ with $\mathrm{Eg}=2.15$.

This agreed with Ugwuoke (2014) for lead halide perovskite. Additionally, $\mathrm{J}_{\mathrm{sc}}$ values obtained in this work shows similar progression with those obtained in Feng et al (2014) Figure 3 gives the results for $\mathrm{V}_{\text {oc }}$ and as can be inferred, a linear curve is obtained with $V_{\text {oc }}$ increasing with

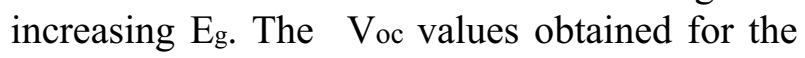
different $\mathrm{Eg}$ shows close proximity with those obtained in Feng et al (2014). The linear increase is attributed to the fact that the dark saturation current density $\left(\mathrm{J}_{0}\right)$ is a measure of recombination process es within the solar cell which reduces significantly with increasing band gap. Hence generating higher $\mathrm{V}_{\text {oc }}$ is achieved with $\mathrm{CH}_{3} \mathrm{NH}_{3} \mathrm{SnBr}_{3}$ where the absorbed flux equals the emitted flux under open circuit condition.

Figure 4 shows the result for FF, and from the graph there is a noticeable quick rise in FF as the Eg increases until a saturation point is reached for higher Eg. The reason for this is that the induced electric field in the absorber material as a result of illumination decreases with increasing forward bias, and the collection of photogenerated carriers which was initially assisted by the electric fields becomes weaker. We obtained the highest $\mathrm{FF}$ values for $\mathrm{CH}_{3} \mathrm{NH}_{3} \mathrm{SnBr}_{3}$, however results obtained in this work shows variation as compared with those from Feng et al., (2014), and can be attributed to the assumption of radiative recombination as the only loss mechanism in this study leading to higher values of $\mathrm{J}_{\mathrm{sc}}$ and $\mathrm{V}_{\mathrm{oc}}$ which are determining factors for $\mathrm{FF}$.

The result for $\eta$ across different Eg values are shown in Figure 5. In this, we obtain highest $\eta$ value for $\mathrm{Eg}$ at $\mathrm{Eg}$ at $1.30 \mathrm{eV}$ as contained in Feng $e t$ al., (2014). Increasing value of Eg however, shows a decrease in $\eta$ especially for $\mathrm{Eg}$ at $1.56 \mathrm{eV}, 1.65 \mathrm{eV}$ and $2.15 \mathrm{eV}$. . Increasing bandgap leads to decreasing efficiency due to the instability of the $\mathrm{Sn}^{2+}$ oxidation state of tin which can easily be oxidized to more stable $\mathrm{Sn}^{4+}$ leading to self-doping 
where the $\mathrm{Sn}^{4+}$ acts as a p-dopant leading to the reduction in the solar cell efficiency (Lee et al., 2016).

\section{Conclusion}

A semi- empirical and theoretical method to determine the efficiency of tin halide perovskite solar sell is presented. The present method show appreciable agreement with the reference method with a difference of about $5.56 \%$ for the efficiency value at optimal band gap energy value. This variation notwithstanding, the objectives of the present method to determine the efficiency parameters of tin halide perovskite solar cells as a means of improving fabrication of tin-based solar cells is achieved.

\section{References}

Amu, T.L. (2014). Performance optimization of Tin-Halide Perovskite solar cells via Numerical Simulation. M.Sc Thesis. African University of Science and Technology, Abuja. 47pp

Chen Q, De Marco N, Yang Y, Song T.B, Chen C.C, Zhao H, Hong Z, Zhou H, Yang Y (2015). Under the spotlight: The organicinorganic hydrid perovskite for optoelectronic applications. Nano Today, 10(11), 42-50

Darrow, K.K. (1923). Some Contemporary Advances in Physics. Bell system Technical Journal, 2(4), 101-115.

Feng, H., Stoumpos, C., Cao, D., Chang, R., and Kanatzidis, M. (2014). Lead-free solidstate organic-inorganic halide perovskites cells. Nature Photonics, 8(6), 489-494

Granas, O., Vinichenko, D., \& Kaxiras, E. (2016). Establishing the limit of efficiency of perovskite solar cells from first principle modeling. Sci. Rep. 6, 36108.

Green, M., Emery, K., Hishikawa, Y., Warta, W., and Dunlop, E. (2013). Solar cell efficiency tables (version 42). Progress in photovoltaics: Reaseach and Applications, 21(5), 827-837

Heo, J.H., Im, S.H., Noh. J.H., Mandal, T.N., Lim, C., Chang, I.A., Lee, Y.H., Kim, H., Sarkar, A., Nazeeruddin, M.K., Gratzel, $M$ and Seok, S.I. (2013). Efficient InorganicOrganic hybrid hetero-junction solar cells containing perovskite compound and polymeric hole conductors. Nature Photonics, 7(6), 486-491.
Lee. S.J., Shin, S.S., Kim, Y.C., Kim, D., Ahn, T.K., Noh, J.H., Seo, J., and Seok, S.L. (2016). Fabrication of Efficient Formamidinium Tin Iodide perovskite solar cells through $\mathrm{SnF}_{2}$ Pyrazine complex. Journal of. American. Chem. Society, 14.

Nelson, J. (2003). The Physics of Solar Cells. Imperial College Press: London, pp. 1325

Noel, N., Stranks, S., Abate, A., Wehrenfenning, C., Guarnera, S., Haghighirad, A., Badhanala, A., Eperon, G.E., Pathak, S.K., Johnston, M.M., Petrozza, A., Herz, L.M., and Snaith, H.J. (2014) Lead-free organic-inorganic Tin Halide Perovskites for photovoltaic applications. Energy Environ. Sci, 7(9), 3061-3068

Snaith H.J., Green, M.A., Ho-Baillie A. (2014). The emergence of Perovskite solar cells, Nat. Photonics, vol. 8, no.7, pp. 506514.

Sha, W.E.I., Ren, X., Chen, L., and Choy, W.C.H. (2015). The efficiency limit of $\mathrm{CH} 3 \mathrm{NH} 3 \mathrm{PbI} 3$ perovskite solar cells. Applied physics letters, 106(22), 221104

Shockley, W and Queisser, H.J. (1961). Detailed Balance Limit of Efficiency of p-n Junction Solar Cells. Journal of Applied Physics, vol. 32, pp. 510-519.

Sun, S., Teddy S, Mathew N, Martial D, Chris B, Xing G, Sum T.C, Yeng M.L.(2014) The origin of high efficiency in low temperature solution-processable bilayer organometal halide hybrid solar cell. Energy Environ. Sci.7, 399-407-399.

Ugwuoke, Luke Chinedu. (2014). Limiting Efficiency of Perovskite solar cells. M.Sc Thesis. African University of Science and Technology Abuja-Nigeria. 47pp.

Van-Roosbroeck, W., and Shockley, W (1954). Photon-Radiative recombination of electrons and holes in Germanium. Physical Review, 94(6), 1558-1560

Wehrenfennig, C., Eperon, G.E., Johnston, M.B., (2014) High charge carrier mobilities and lifetimes in organo lead trihalide perovskites, Adv. Mater., vol. 26, no. 10, pp. 1584-1589.

Xiangang, R., Wang, Z., Sha, W.E.I., Chou, W.C.H. (2017). Exploring the way to approach the efficiency limit of perovskite solar cells by drift-diffusion Model. Acs Photonics, 4(4), 934-942. 
